Haya: The Saudi Journal of Life Sciences

Abbreviated Key Title: Haya Saudi J Life Sci ISSN 2415-623X (Print) |ISSN 2415-6221 (Online) Scholars Middle East Publishers, Dubai, United Arab Emirates Journal homepage: http://scholarsmepub.com/haya/

Original Research Article

\title{
Assessing the Feasibility of Growing Some Imported Plants for Combating Desertification Using Matk and Rbcl Markers
}

\author{
Faten Dhawi ${ }^{1 *}$ and Sumayah I. Alsanie ${ }^{2}$ \\ ${ }^{1}$ Biotechnology Department, College of Agriculture and Food Sciences, King Faisal University, Saudi Arabia \\ ${ }^{2}$ Biology Departemnt, College of Science, Imam Abdulrahman Bin Faisal University, Saudi Arabia
}

\begin{tabular}{lr}
\hline DOI: $10.36348 /$ SJLS.2019.v04i10.002 & $\mid$ Received: $28.10 .2019 \mid$ Accepted: 05.11.2019| Published: 08.11.2019 \\
*Corresponding author: Faten Dhawi & Email: dr.faten.dhawi@ gmail.com; falmuhanna @kfu.edu.sa
\end{tabular}

Abstract

In the current study, we tested the feasibility of using three species of imported plants to combat desertification in Saudi Arabia. Delonix regia, Jacaranda mimosifolia, and Simmondsia chinensis were chosen for the evaluation because they have previously been reported to have marked drought and heat tolerance characteristics. To examine the feasibility of using these non-native plants for the mitigation of desertification, we aimed to determine the evolutionary relationships between the imported and local plants. DNA extracted from the non-native plants was compared with that of 45 local taxa. Two genes, Maturase $\mathrm{K}(\mathrm{matK})$ and ribulose-1,5-bisphosphate carboxylase/oxygenase large subunit ( $r b c L)$, were sequenced and aligned for all species of imported and local plants analyzed in this study. The two molecular markers are known to be evolutionary conserved. A molecular phylogenetic tree was generated using the local and imported plants, and it showed similarity between Delonix regia and Cassia senna, indicating that they belong to the same family (Leguminosae). Similarly, Jacaranda mimosifolia (a member of Bignoniaceae) was found to be closely related to the local plants Plantago ovata and P. arenaria. Simmondsia chinensis was determined to be distantly related to many taxa of flora found in Saudi Arabia. The results of molecular analysis and the physiological features of Delonix regia and Jacaranda mimosifolia indicate that both species are closely related to Saudi Arabia flora, more so than Simmondsia chinensis.

Keywords: DNA barcoding; arid plants; matK; $r b c L$; molecular tools.

Copyright @ 2019: This is an open-access article distributed under the terms of the Creative Commons Attribution license which permits unrestricted use, distribution, and reproduction in any medium for non-commercial use (NonCommercial, or CC-BY-NC) provided the original author and source are credited.

\section{INTRODUCTION}

Vegetation is the most important factor in environmental preservation because it facilitates a decrease in pollution, mitigates climate change, prevents soil encroachment, and improves soil fertility. Vegetation enhancement in Saudi Arabia faces many challenges, such as the loss of $10 \%$ of plant varieties in Baha- a small fertile land in the south of the country. In addition, the cultivated land in Saudi Arabia represents $7 \%$ of the total land area, of which $40 \%$ is affected by salinity, and $67 \%$ suffers from erosion [1]. All of these factors contributed to the decline in Saudi Arabia's Environmental Performance Index in 2018, resulting in the country ranking 86 out of 180 countries $[2]$.

The preservation of ecosystems is an area of concern, especially in arid and semiarid countries such as Saudi Arabia. In such countries, the climate may be heavily affected by a reduction in flora since trees and shrubs have a substantial influence on the shaping and preservation of ecosystems [3]. To address the ongoing loss of flora, the Saudi government sponsored an initiative to plant one million trees. The implementation of this tree-planting initiative was organized by Saudi Aramco within the framework of the Saudi Arabia 2030 vision to preserve and enrich natural resources across the country [4].

There have been many attempts to plant imported trees and shrubs in Saudi Arabia to enhance vegetation and mitigate the hot weather across the country. However, assessing the feasibility of planting new species is time-consuming and may disturb the natural ecosystem. The natural flora of Saudi Arabia comprises approximately $25 \%$ shrubs and only $4.3 \%$ trees [5]. The majority of vegetation is annual herbs, which constitute the plant cover of more than $70 \%$ of the fertile land [5]. The most dominant tree species in Saudi Arabia are acacias. The flora of Saudi Arabia is similar to that in other Arabian Peninsula countries, with 2282 species belonging to 855 genera in 131 
families - approximately one-third are gymnosperms, and two-thirds are pteridophytes. Most of the native tree species are distributed in the southwestern regions and parts of the Hijaz [6-8].

The semiarid weather in Saudi Arabia requires plant species with a high tolerance for drought and salinity and resistance to native pathogens. Notably, at least one imported species, Simmondsia chinensis, appears to be prone to infection by phytoplasma in the Qassim region [8].

In the current study, we used molecular markers to examine the feasibility of cultivating three non-native plant species in Saudi Arabia. Two specific genes, matK (Maturase K) and plastid $r b c L$ (ribulose1,5-bisphosphate carboxylase/oxygenase large subunit), were used for the assessment. This type of molecular assessment has been used to identify the evolutionary relationships between taxa; such genetic tools (matK and $r b c L$ ) are highly conserved and minimally affected by environmental influences [9].

We assessed three imported plants-Delonix regia, Jacaranda mimosifolia, and Simmondsia chinensis - to determine their relationships with 45 taxa of Saudi flora belonging to 22 families (Aizoaceae, Amaranthaceae, Asteraceae, Bignoniaceae, Caryophyllaceae, Compositae, Convolvulaceae, Cyperaceae, Euphorbiaceae, Geraniaceae,
Leguminosae, Malvaceae, Phyllanthaceae, Plantaginaceae, Poaceae, Polygonaceae, Portulacaceae, Primulaceae, Resedaceae, Solanaceae, Tamaricaceae, and Zygophyllaceae). The data analysis indicated that Delonix regia and Jacaranda mimosifolia have a strong evolutionary relationship with some Saudi taxa.

\section{MATERIAL AND METHODS Plant material}

The native plant samples included 45 taxa from the central, western, and eastern regions of Saudi Arabia, and the three imported plants were Delonix regia, Jacaranda mimosifolia, and Simmondsia chinensis (Table 1). The molecular markers Maturase K (matK) and ribulose-1,5-bisphosphate carboxylase/oxygenase large subunit $(r b c L)$ were used because they are known to be highly conserved and minimally affected by environmental factors [9].

Seven dried leaf samples from each plant were homogenized to obtain a fine powder, which was then subjected to DNA extraction. Following DNA extraction using the DNeasy Plant Mini Kit (Qiagen, Germany), the purity and quantity of the DNA were determined with a NanoDrop spectrophotometer. DNA samples with a concentration of $50 \mathrm{ng} / \mu \mathrm{L}$ were subjected to marker sequencing for $m a t K$ and $r b c L$ using Macrogen (Macrogen Inc. Seoul, South Korea).

Table-1: Identification and locations of native plants in Saudi Arabia and the identification of imported plants

\begin{tabular}{|l|l|r|}
\hline \multicolumn{1}{|c|}{ Sample name } & \multicolumn{1}{c|}{ Family } & \multicolumn{1}{c|}{ Location } \\
\hline Aizoanthemum hispanicum & Aizoaceae & $27.126807,43.632498$ \\
\hline Anagallis arvensis & Primulaceae & $26.406813,50.084008$ \\
\hline Anthemis melampodina deserti & Compositae & $27.126807,43.632498$ \\
\hline Brassica rapa & Brassicaceae & $26.406813,50.084008$ \\
\hline Cassia senna & Leguminosae & $23.619410,46.479307$ \\
\hline Caylusea hexagyna & Resedaceae & $26.431779,49.820577$ \\
\hline Cenchrus pennisetiformis & Poaceae. & $26.154051,49.432576$ \\
\hline Chenopodium murale & Amaranthaceae & $26.427237,49.990864$ \\
\hline Convolvulus arvensis & Convolvulaceae & $26.406813,50.084008$ \\
\hline Convolvulus cephalopods & Convolvulaceae & $26.431779,49.820577$ \\
\hline Conyza bonariensis & Compositae & $26.406813,50.084008$ \\
\hline Coronopus didymus & Brassicaceae & $26.395233,50.097260$ \\
\hline Cyperus rotundus & Cyperaceae & $26.429227,50.093481$ \\
\hline Delonix regia & Leguminosae (Fabaceae) & imported \\
\hline Echium horridum & Boraginaceae & $27.126807,43.632498$ \\
\hline Eclipta prostrata & Compositae & $26.406813,50.084008$ \\
\hline Eremobium aegyptiacum & Brassicaceae & $27.126807,43.632498$ \\
\hline Erucastrum arabicum & Brassicaceae & $27.126807,43.632498$ \\
\hline Euphorbia hirta & Euphorbiaceae & $26.431779,49.820577$ \\
\hline Fagonia cretica & Zygophyllaceae & $27.126807,43.632498$ \\
\hline Gamochaeta pensylvanica & Compositae & $26.406813,50.084008$ \\
\hline Heliotropium curassavicum & Boraginaceae & $26.406419,50.092900$ \\
\hline Jacaranda mimosifolia & Bignoniaceae & imported \\
\hline Launaea cassiniana & Compositae & $26.126807,43.632498$ \\
\hline Malva parviflora & Malvaceae & $26.406813,50.084008$ \\
\hline Melilotus indicus & Leguminosae & \\
\hline
\end{tabular}


Faten Dhawi \&Sumayah I. Alsanie., Haya Saudi J Life Sci, Nov., 2019; 4(10): 340-345

\begin{tabular}{|l|l|r|}
\hline Monsonia heliotropioides & Geraniaceae & $26.316269,49.941869$ \\
\hline Oligomeris linifolia & Resedaceae & $26.406813,50.084008$ \\
\hline Paronychia desertorum & Caryophyllaceae & $26.154051,49.432576$ \\
\hline Pennisetum divisum & Poaceae & $26,412477,50.097858$ \\
\hline Phyllanthus niruri & Phyllanthaceae & $26.406813,50.084008$ \\
\hline Plantago ovata & Plantaginaceae & $26.264355,50.139338$ \\
\hline Plantago arenaria & Plantaginaceae & $26.413044,50.041311$ \\
\hline Polypogon monspeliensis & Poaceae & $26.413044,50.041311$ \\
\hline Portulaca oleracea & Portulacaceae & $26.406419,50.092900$ \\
\hline Rumex vesicarius & Polygonaceae & $26.406419,50.092900$ \\
\hline Salsola baryosma & Amaranthaceae & $26.264355,50.139338$ \\
\hline Savignya parviflora & Brassicaceae & $27.126807,43.632498$ \\
\hline Schismus barbatus & Poaceae & $26.431779,49.820577$ \\
\hline Senecio desfontainei & Compositae & $26.605973,49.921483$ \\
\hline Setaria glauca & Poaceae & $26.406813,50.084008$ \\
\hline Simmondsia chinensis & Simmondsiaceae & imported \\
\hline Solanum nigrum & Solanaceae & $27.123450,49.537920$ \\
\hline Sonchus asper & Asteraceae & $26.427237,49.990864$ \\
\hline Sonchus oleraceus & Asteraceae & $26.406813,50.084008$ \\
\hline Spergularia marina & Caryophyllaceae & $27.126807,43.632498$ \\
\hline Tamarix nilotica & Tamaricaceae & $26.431779,49.820577$ \\
\hline Tribulus iongipetalus & Zygophyllaceae & $26,412477,50.097858$ \\
\hline Zygophyllum hamiensis & Zygophyllaceae & $26,753197,50.013822$ \\
\hline
\end{tabular}

\section{DATA ANALYSIS}

A molecular phylogenetic analysis was performed using matK and $r b c L$ for 45 taxa belonging to 22 families of Saudi Arabia flora and for the three imported plants (Delonix regia, Jacaranda mimosifolia, and Simmondsia chinensis) (Table 1).

A DNA sequence analysis for both markers was applied to the 49 plant taxa using MEGA6 software [10]. A maximum likelihood model was used as described by Tamura et al. [10]. Briefly, the sequences were aligned, and phylogenetic trees were constructed for both markers ( $m a t K$ and $r b c L$ ) using the neighborjoining method with bootstrap testing for 500 replicates to increase the confidence of the consensus tree topology. The evolutionary distances were computed using the Maximum Composite Likelihood analysis for the 49 nucleotide sequences. Bootstrap values greater than or equal to 0.5 were labeled on the tree.

\section{RESULTS}

The 45 taxa belonging to 22 families of Saudi Arabia flora were clustered mainly in the eastern, northcentral, and central regions of the country (Fig. 1a). Molecular analysis showed evolutionarily related clusters in the eastern and central regions (Fig. 1b). When considering both markers (matK and $r b c L$ ), we found that Delonix regia is closely related to Cassia senna, which both belong to the family Leguminosae. The same markers indicated that Jacaranda mimosifolia, a member of Bignoniaceae, is closely related to both Plantago ovata and $P$. arenaria, which are members of Plantaginaceae. Simmondsia chinensis, a member of Simmondsiaceae, was found to be closely related to Portulaca oleracea (Plantaginaceae) from the mat $K$ sequence analysis, while the $r b c L$ marker showed only a distant relationship between the two species (Figs. 2-4).

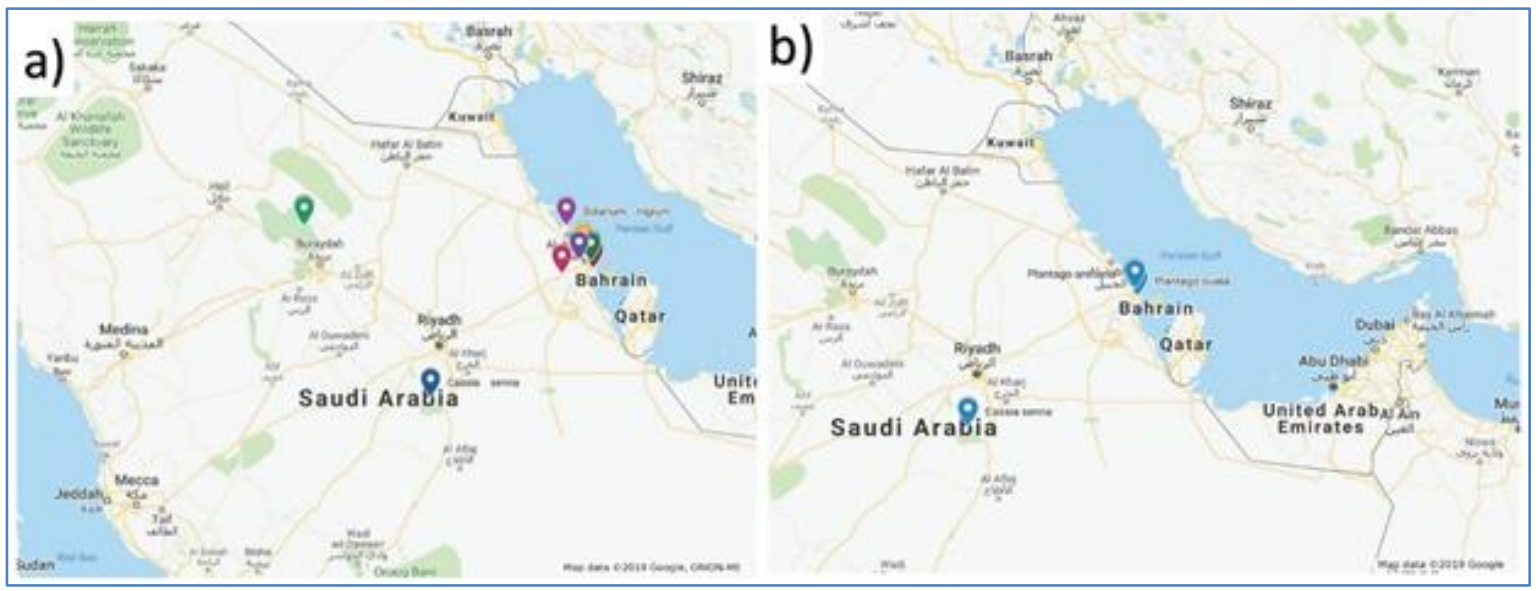

Fig-1: The locations of plant samples within Saudi Arabia. a) All native species. b) Species closely related to the imported plants. 

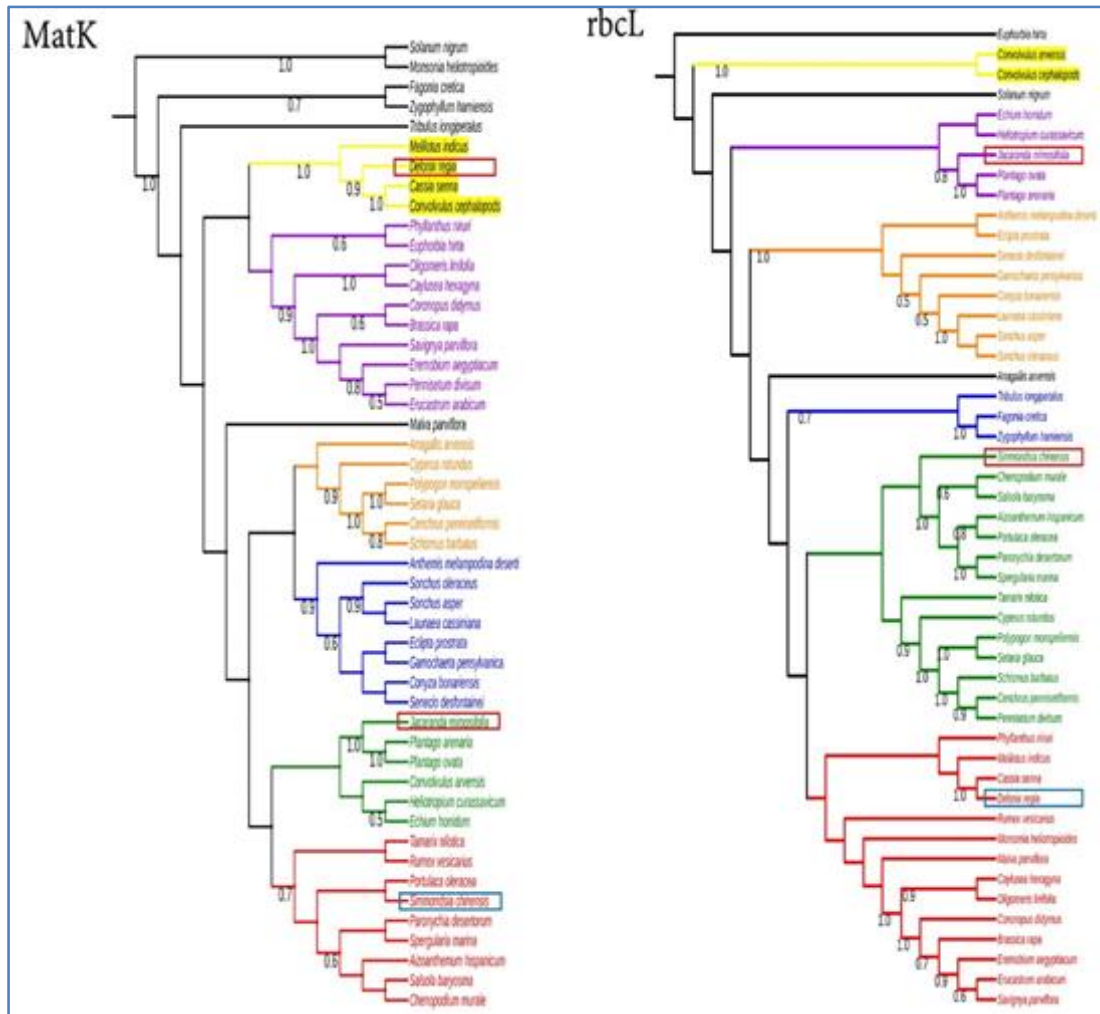

Fig-2: Molecular phylogenetic analysis using matK(left) and rbcL (right) for 46 taxa belongs to 23 families of Saudi Arabia flora and three imported plants labeled (Delonix regia, Jacaranda Mimosifolia and Simmondsia chinensis). The maximum-likelihood model applied using the neighbor-joining method based on Tamura et al. (2013). The evolutionary distances were computed using the Maximum Composite Likelihood for 49 nucleotide sequences. Evolutionary analyses were conducted in MEGA6. The numbers below branches are the Bootstrap values. The bootstrap greater than or equal to 0.5 are shown

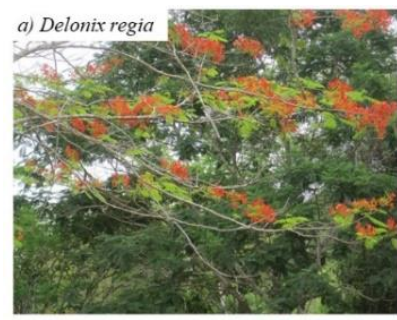

c) Simmondsia chinensis $47 \mathrm{~N})$ Wh
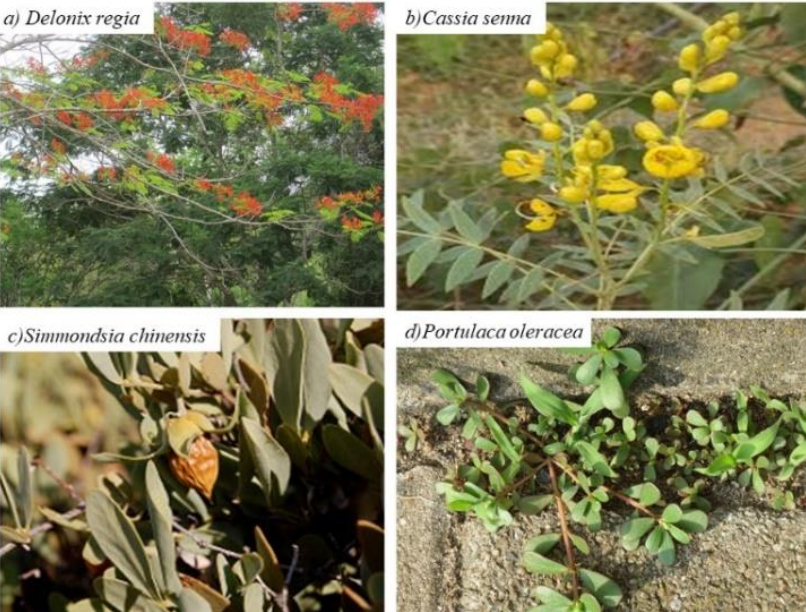

Fig-3: The related plants according to the molecular markers

matK and rbcL analysis under the study represented by the imported plant $a$ ) Delonix regia that is closely related to b) Cassia senna and $c$ )Simmondsia chinensis another imported plant that closely related to d) Portulaca oleracea. (Photo by: Ateah Alfakih and Andreas Rockstein)

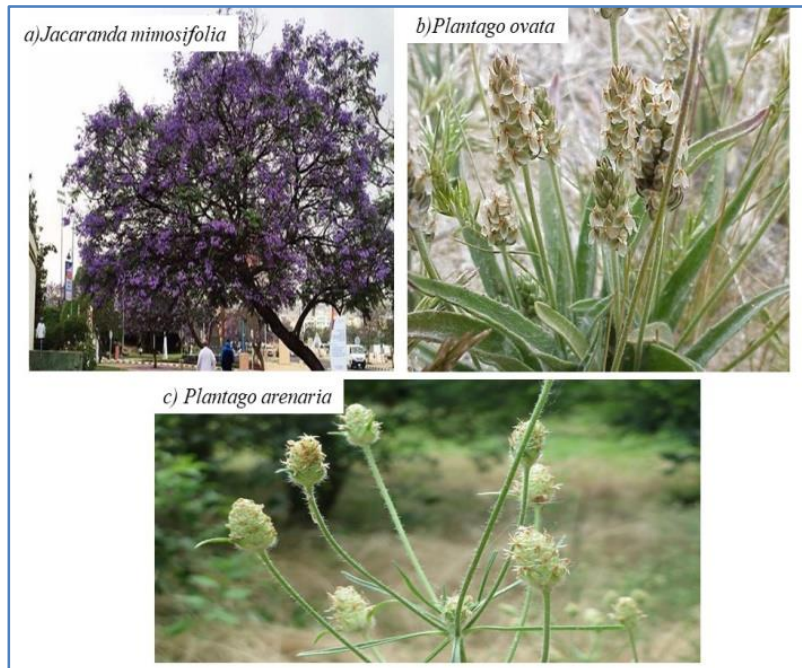

Fig-4: Taxonomy according to molecular markers matK and rbcL for the imported plant a) Jacaranda mimosifolia, found to be closely related to both b) Plantago ovata and c) Plantago arenaria.

(Photo by Andreas Rockstein)

\section{DISCUSSION}

Plants play a fundamental part in the moderation of temperature and the balancing of ecosystems [11]. This has made countries such as Saudi Arabia realize the importance of vegetation-related initiatives. The government of Saudi Arabia has supported an initiative by Saudi Aramco, one of the 
biggest companies in the oil industry, to plant trees in the nation. However, the enthusiasm behind such initiatives to mitigate climate change should not lead us to neglect the full assessment of imported plants' molecular and physiological features, which might disturb natural flora or result in irreversible damage to the ecosystem.

We aimed to determine the suitability of three non-native plants for planting in Saudi Arabia. The three imported plants were Delonix regia and Jacaranda mimosifolia, drought-tolerant trees with shallow root systems [12], and Simmondsia chinensis, a shrub that tolerates saline soils [13]. Jacaranda trees have been planted in the southwest region of Saudi Arabia (Abha city), and Delonix regia trees have been planted in the east and central regions. S. chinensis has been planted in the western region of Saudi Arabia (in both Madinah and Jeddah) since 2001 [1], and it has been planted in the Hail and Qassim regions for research purposes [16] .

We evaluated the imported plants using two molecular markers, mat $K$ and $r b c L$. These chloroplast genes were described in 2009 by the Plant Working Group in Consortium for the Barcode of Life [15]. Many studies have used $r b c L$ and matK DNA barcoding to identify species and study evolutionary relationships and biodiversity [16-20].

In a species identification study, species identification with $r b c L$ had a $41.50 \%$ success rate, and identification with matK had a success rate of $42.88 \%$ [21]. On the other hand, the success rate of PCR amplification was higher for $r b c L(75.26 \%)$ than that for $\operatorname{matK}(57.24 \%)$ [21]. Thus, the use of two or more molecular markers has been shown to enhance the quality of the resulting evolutionary tree $[22,21]$.

By considering both markers (matK and $r b c L$ ), we found that D. regia is closely related to Cassia senna, a member of the same family (Leguminosae). Jacaranda mimosifolia, a member of Bignoniaceae, was found to be closely related to both Plantago ovata and $P$. arenaria, members of Plantaginaceae in the order Lamiales.

The matK and $r b c L$ results for J. mimosifolia and $D$. regia indicated that the two plants were related to native plants to equal extents. The same was not true for S. chinensis. S. chinensis, which belongs to the family Simmondsiaceae, was found to be closely related to Portulaca oleracea (a member of Plantaginaceae, order Caryophyllales) according to the matK sequence analysis. However, the analysis of $r b c L$ indicated only a distant relationship between $S$. chinensis and P. oleracea.

Overall, the $r b c L$ marker analysis agreed with Adolf Engler's classification [23] and has been reported to have a higher amplification rate and universality $[24$,
25] than those of matK. The matK marker, located in the chloroplast coding region, has been reported to have an evolution rate that is $2-3$ times higher than that of $r b c L$ [26, 27]; thus, in the current study, it is not surprising that $r b c L$-based relationships were more pronounced in the taxonomic results for the imported plants. The data analysis indicated that both Delonix regia and Jacaranda mimosifolia have a strong evolutionary relationship with some Saudi taxa. Because our results suggest that Delonix regia and Jacaranda mimosifolia will have the ability to adapt and spread widely across the country, we recommend the planting of these two tree species.

\section{CONCLUSION}

We performed a phylogenetic analysis using mat $K$ and $r b c L$ for 45 taxa belonging to 22 families of Saudi Arabia flora and three imported plants (Delonix regia, Jacaranda mimosifolia and Simmondsia chinensis), and we found that two plants, Delonix regia and Jacaranda mimosifolia, are better candidates for planting in Saudi Arabia than Simmondsia chinensis. The phylogenetic analysis can provide decision-makers with deeper insight into the fulfillment of desirable environmental traits, allowing them to manage and implement imported plants to sustain balanced biodiversity. Thus, it is necessary to use molecular markers, such as the two genes used in the current study, $m a t K$ and $r b c L$, to predict the feasibility of planting new species. On the basis of our results, we suggest that further work be done to evaluate newly cultivated species in the field within two years of planting.

\section{Author Contributions}

The authors contributed equally to project funding, data .collection, analysis, and manuscript writing

\section{Conflicts of Interest}

Authors declare no conflict of interest.

\section{REFERENCE}

1. Bafeel, S. O., Galal, H. K., \& Basha, A. Z. (2016). Effect of seawater irrigation on growth and some metabolites of jojoba plants. American-Eurasian Journal of Agricultural and Environmental Sciences, 16(1), 49-59.

2. https://epi.envirocenter.yale.edu/

3. Barrios, E., Valencia, V., Jonsson, M., Brauman, A., Hairiah, K., Mortimer, P. E., \& Okubo, S. (2018). Contribution of trees to the conservation of biodiversity and ecosystem services in agricultural landscapes. International Journal of Biodiversity Science, Ecosystem Services \& Management, 14(1), 1-16.

4. https://www.saudiaramco.com/en/newsmedia/news/2018/one-million-trees-initiative

5. Alfarham, A. H., Thomas, J. A. C. O. B., \& Alallah, M. I. (1997). Noteworthy records to the 
Flora of Saudia Arabia. Kuwait Journal of Science and Engineering, 24, 123-130.

6. Thomas, J., El-Sheikh, M. A., Alfarhan, A. H., Alatar, A. A., Sivadasan, M., Basahi, M., ... \& Rajakrishnan, R. (2016). Impact of alien invasive species on habitats and species richness in Saudi Arabia. Journal of Arid Environments, 127, 53-65.

7. El-Sheikh, M. A., Thomas, J., Alfarhan, A. H., Alatar, A. A., Mayandy, S., Hennekens, S. M., \& Alansari, A. M. (2017). SaudiVeg ecoinformatics: Aims, current status and perspectives. Saudi journal of biological sciences, 24(2), 389-398.

8. Al-Obaid, S., Samraoui, B., Thomas, J., ElSerehy, H. A., Alfarhan, A. H., Schneider, W., \& O'connell, M. (2017). An overview of wetlands of Saudi Arabia: Values, threats, and perspectives. Ambio, 46(1), 98-108.

9. Uncu, A. O., Uncu, A. T., Celık, I., Doganlar, S., \& Frary, A. (2015). A primer to molecular phylogenetic analysis in plants. Critical reviews in plant sciences, 34(4), 454-468.

10. Tamura, K., Stecher, G., Peterson, D., Filipski, A., \& Kumar, S. (2013). MEGA6: molecular evolutionary genetics analysis version 6.0. Molecular biology and evolution, 30(12), 27252729.

11. Wohlgemuth, D., Solan, M., \& Godbold, J. A. (2017. Species contributions to ecosystem process and function can be population dependent and modified by biotic and abiotic setting. Proceedings of the Royal Society B: Biological Sciences, 284(1855), 20162805.

12. Ricks, G. (1992). Landscape plant manual for Saudi Arabia. Scientific Publ. Centre, King Abdulaziz Univ.

13. Harsh, L. N., Tewari, J. C., Patwal, D. S., \& Menna, G. L. (1987). Package of practices for cultivation of jojoba (Simmondsia chinensis) in arid zone.

14. Al-Soqeer, M. (2014). Evaluation of seven jojoba(Simmondsia chinensis) clones under Qassim region conditions in Saudi Arabia. International Journal of Agricultural Science Research, 3(10), 203-212.

15. CBOL Plant Wording Group(2009).. A. DNA barcode for land plants. PNAS 106, 12794-12797

16. Cuénoud, P., Savolainen, V., Chatrou, L. W., Powell, M., Grayer, R. J., \& Chase, M. W. (2002). Molecular phylogenetics of Caryophyllales based on nuclear $18 \mathrm{~S}$ rDNA and plastid rbcL, atpB, and
matK DNA sequences. American Journal of Botany, 89(1), 132-144.

17. Hollingsworth, P. M., Graham, S. W., \& Little, D. P. (2011). Choosing and using a plant DNA barcode. PloS one, 6(5), e19254.

18. Bafeel, S. O., Arif, I. A., Bakir, M. A., Al Homaidan, A. A., Al Farhan, A. H., \& Khan, H. A. (2012). DNA barcoding of arid wild plants using rbcL gene sequences. Genet Mol Res, 11(3), 1934-1941.

19. Wattoo, J. I., Saleem, M. Z., Shahzad, M. S., Arif, A., Hameed, A., \& Saleem, M. A. (2016). DNA Barcoding: Amplification and sequence analysis of rbcl and matK genome regions in three divergent plant species. Advancements in Life Sciences, 4(1), 03-07.

20. Pei, N., Chen, B. \& Kress, W. J. Advances of community-level plant DNA barcoding in China. Frontiers in plant science 8, 225 (2017).

21. Kang, Y., Deng, Z., Zang, R., \& Long, W. (2017). DNA barcoding analysis and phylogenetic relationships of tree species in tropical cloud forests. Scientific reports, 7(1), 12564.

22. Newmaster, S. G., Fazekas, A. J., \& Ragupathy, S. (2006). DNA barcoding in land plants: evaluation of rbcL in a multigene tiered approach. Botany, 84(3), 335-341.

23. Croat, T. B. (1990). A comparison of aroid classification systems. Aroideana, 13, 44-63.

24. Chase, M. W. et al. A proposal for a standardised protocol to barcode all land plants. Taxon 56, 295-299 (2007).

25. Hollingsworth, P. M., Li, D. Z., van der Bank, M., \& Twyford, A. D. (2016). Telling plant species apart with DNA: from barcodes to genomes. Philosophical Transactions of the Royal Society B: Biological Sciences, 371(1702), 20150338.

26. Wolfe, K. H. CHAPTER 15-Protein-Coding Genes in ChloroplastDNA: Compilation of Nucleotide Sequences, Data Base Entries, and Rates of Molecular Evolution. Photosynth. Appa. Mol. Biol. Oper. 467-482 (1991).

27. Gadek, P. A., Alpers, D. L., Heslewood, M. M., \& Quinn, C. J. (2000). Relationships within Cupressaceae sensu lato: a combined morphological and molecular approach. American journal of botany, 87(7), 1044-1057.

28. https://www.mewa.gov.sa/ar/InformationCenter/D ocsCenter/YearlyReport/Pages/default.aspx 